\title{
NAARA LUNA Pessoa e parentesco nas novas
tecnologias reprodutivas
}

Resumo: O trabalho trata do universo de representações das novas tecnologias reprodutivas, refletindo sobre as implicações desses procedimentos para as noções ocidentais de pessoa e de parentesco. Tais técnicas incidem no modo ocidental de pensar a reprodução e o domínio da natureza. A abordagem sobre pessoa se detém em textos relacionados à figura do embrião extracorporal gerado por meio da fertilização in vitro. A análise do parentesco enfoca como as novas tecnologias reprodutivas reconfiguram as representações de parentesco e, reciprocamente, de que forma as concepções ocidentais de parentesco constituem a compreensão das tecnologias, levando em conta crenças ocidentais sobre a natureza enquanto fundamento da realidade. A pesquisa utiliza como material para análise matérias sobre novas tecnologias reprodutivas publicadas na grande imprensa brasileira entre os anos de 1994 e 2000.

Palavras-chave: novas tecnologias reprodutivas, pessoa, parentesco, embrião, natureza.

\begin{abstract}
1 A expressão "novas tecnologias reprodutivas" é utilizada particularmente por estudiosos com interesse na área de gênero, enfatizando - aspecto técnico de intervenção nas pessoas, enquanto "reprodução assistida" é um termo empregado no meio médico para auxílio à procriação. As técnicas mencionadas neste artigo são a inseminação artificial (IA), a fertilização in vitro (FIV ou FIVETE, fertilização in vitro e transferência embrionária), conhecida popularmente como "bebê de proveta", e a ICSI (injeção intracitoplasmática de espermatozóide), além de menções à clonagem.
\end{abstract}

${ }^{2}$ NOVAES e SALEM, 1995, p. 69.
O presente trabalho trata do universo de representações das novas tecnologias reprodutivas ou reprodução assistida, técnicas que viabilizam a concepção da vida humana por meio de procedimentos médicos, dispensando o ato sexual. ${ }^{1}$ Este artigo pretende aprofundar alguns tópicos no tocante às implicações desses procedimentos para as noções ocidentais de parentesco e pessoa.

A transferência do ato reprodutivo da esfera privada, da família, para o contexto de laboratório é a operação principal realizada pelas novas tecnologias reprodutivas. ${ }^{2}$ Tais técnicas afetam a maneira de criar pessoas até então considerada no Ocidente uma decorrência da relação sexual. O parentesco é o sistema sócio-cultural responsável pela regulação da formação de pessoas, unindo aspectos biológicos e sociais da reprodução na cultura ocidental moderna. Os momentos da concepção e do parto seriam ocasiões privilegiadas de criar relações e lhes dar significado. Ao colocar o ser nascido na rede de relações preexistente, a concepção e o nascimento também vão lhe conferir uma identidade específica. Este trabalho aborda o impacto das novas tecnologias reprodutivas sobre as relações sociais implicadas no parentesco e na aquisição da identidade de 
3 COLLIER E YANAGISAKO (1987) propõem a abordagem conjunta desses temas, pois, embora os estudos de gênero estejam mais centrados na relação entre homens e mulheres, e os de parentesco na grade genealógica, ambos têm como base a concepção ocidental nativa dos fatos biológicos da reprodução sexual. O deslocamento do ato reprodutivo da esfera privada para o contexto de laboratório incide tanto sobre as relações de gênero como sobre as de parentesco, afetando as oposições conceituais entre doméstico e público, e entre natureza e cultura que têm orientado os campos de estudo de gênero e de parentesco.

${ }^{4}$ EDWARDS et al., 1999b, p. 35.

${ }^{5}$ Sobre a tarefa humana de submeter a natureza veja SCHNEIDER, 1968, p.107.

${ }^{6} \mathrm{Em}$ trabalho anterior (LUNA, 2000) fiz um mapeamento sistemático de material de imprensa obtido de duas formas diferentes: 1) clipagem de notícias no tema inseminação artificial dos periódicos Folha de $S$. Paulo, Isto é, Jornal do Brasil, O Dia, O Estado de S. Paulo e O Globo dos anos de 1994, 1995 e 1996 realizada pela Agência JB de Notícias; 2) busca pelas palavras-chave inseminação e fertilização no banco de dados das edições do Jornal do Brasil dos anos de 1997 e 1998. As matérias sob análise aqui foram selecionadas desse conjunto maior acrescido de clipagem pessoal no jornal $O$ Globo dos anos de 1999 e 2000. pessoa. Questões acerca de gênero e família também estão conjugadas à análise sobre a formação do parentesco e à condição de pessoa humana, a partir da compreensão de que gênero e parentesco se constituem mutuamente. ${ }^{3} \mathrm{~A}$ abordagem sobre pessoa deter-se-á em textos relacionados à figura do embrião gerado por meio da procriação assistida. A análise do parentesco enfocará como as novas tecnologias reprodutivas reconfiguram as representações de parentesco e, reciprocamente, de que forma as concepções ocidentais de parentesco constituem a compreensão das tecnologias. Nesse sentido, a reflexão sobre pessoa e parentesco no tocante às tecnologias de procriação abordará as crenças nativas sobre a natureza como fundamento da realidade passível de ser afetado pelas técnicas.

A inspiração teórica para as principais questões abordadas neste texto vem de Marilyn Strathern. Juntamente com um grupo de pesquisadores, essa autora adverte para a mudança acarretada pelas novas tecnologias reprodutivas no estudo do parentesco, ampliando-o para um domínio complexo de relações humanas e técnicas do qual participa o campo da medicina reprodutiva com instituições técnicas, mercados e alianças profissionais. Em diversos domínios como - lar, a mídia, o poder legislativo, as clínicas encontram-se representações do parentesco com respeito à procriação assistida. ${ }^{4}$ A relevância desses procedimentos médicos não está apenas relacionada com as pessoas diretamente envolvidas no tratamento, visto seu alcance ir muito além da esfera clínica. Seu impacto diz respeito à forma pela qual o ser humano se pensa reproduzindo a si mesmo e dominando a natureza, um valor característico do imaginário ocidental. ${ }^{5}$ A importância do estudo das representações a respeito das tecnologias de procriação está em seu desafio ao modo de pensar sobre a reprodução.

A pesquisa sobre representações privilegiou como material para análise matérias sobre novas tecnologias reprodutivas publicadas na grande imprensa brasileira entre os anos de 1994 e 2000 . O recorte desse extenso universo de notícias foi temático, detendo-se naquelas em que fossem encontradas representações mais expressivas concernentes à concepção de pessoa, e ao parentesco e sua formação. ${ }^{6}$ Também integram o material pesquisado algumas páginas da Internet e dois artigos jurídicos.

\section{A Nova Figura de Pessoa}

Com o advento da FIVETE (fertilização in vitro e transferência do embrião para o útero), os gametas masculino e feminino são conjugados fora do corpo materno, obtendose o chamado "embrião de laboratório". Cria-se a situação 
NAARA LUNA

7 Dumont é o autor mais representativo para a análise da categoria de pessoa humana no Ocidente. DUMONT, 1992, p. 13-30; DUMONT, 1997, p. 49-67, 30316.

${ }^{8}$ Para uma análise detalhada do debate sobre a regulamentação da pesquisa com embrióes e dos serviços de infertilidade na Inglaterra veja FRANKLIN, 1999, p. 127165. O estudo do debate legislativo permitiu à autora $\mathrm{o}$ acesso a uma situação atual de negociação de laços e obrigações de parentesco.

9 "Franceses não querem mãe de aluguel". Jornal do Brasil. 13 jan. 1994. Ciência, p. 9.

10 "Embriões não são seres humanos na França". Folha de S. Paulo. 21 jan. 1994. Atmosfera, p. 1,8. para o debate sobre a condição desse ente: trata-se de um mero aglomerado de células ou deve-se encará-lo como um ser humano? Que atributos o definiriam ou não como uma pessoa humana dotada de direitos e dignidade? Com maior freqüência, foram encontrados indícios desse debate referindo-se a duas situações práticas. A primeira diz respeito à realização de experimentos com embriões. No segundo caso, são regulados juridicamente os direitos desse ser com referência ao parentesco, tratando-se de questões de herança e tutela, em suma, de estabelecer sua relação com os doadores de material reprodutivo para sua formação, seus 'pais'.

Pretendo verificar quais tipos de representações sobre o embrião no tocante à sua condição de pessoa humana surgem no material analisado. Minha hipótese é de que tal representação deva coincidir com a categoria de pessoa hegemônica no Ocidente moderno que é a de 'indivíduo'. ${ }^{7}$ Para tanto, a análise dos textos vai apreender que atributos mencionados confeririam ao embrião subjetividade e identidade individual. As notícias foram agrupadas conforme diferentes aspectos do debate sobre a condição do embrião: a regulamentação de seu estatuto, sua custódia, a tese do embrião como ser humano individual, além de um estudo de caso: a polêmica sobre a destruição de embriões congelados na Inglaterra. Diferentes atores los pais, representantes da Igreja Católica, do aparato jurídico, da comunidade científica, dos médicos e outros integrantes da sociedade civil) se posicionam constituindo o debate sobre a condição do embrião.

\section{A regulamentação do estatuto do embrião ${ }^{8}$}

Constata-se uma necessidade explícita de regulamentar legalmente não apenas as práticas envolvendo a reprodução assistida, mas também que tipo de ser é o embrião, definindo-lhe o lugar social. A regulamentação das novas tecnologias reprodutivas na França em 1994 limitou a aplicação de técnicas de reprodução assistida a "maridos estéreis casados com mulheres na idade de procriar". O cardeal de Paris diz que a existência de embriões excedentes conduz a experiências e manipulações eugênicas, indignando-se com a existência de "uma população fantasma de vários milhões (sic) de embriões congelados". Ainda na França, os embriões não foram reconhecidos legalmente como "seres humanos em potencial", a fim de impedir a reabertura do debate sobre o aborto no país. A despeito de não serem considerados seres humanos, foram baixadas na França leis rigorosas sobre experimentos com embriões. ${ }^{10}$ No mesmo ano, outro artigo coloca a 
11 "Embriões têm direito a herança". Folha de S. Paulo. 5 jun. 1994. Cotidiano, p. 410.

${ }^{12}$ CIMONS, Marlene. "EUA criam regras para embriões de laboratório". Jornal do Brasil. 28 set. 1994. Ciência, p. 14.

13 "Destino de embriões mobiliza a Inglaterra: ovos humanos congelados devem ser destruídos se 'pais' não forem achados". Jornal do Brasil. 3 fev. 1996. Ciência, p. 7. preocupação de especialistas do mundo inteiro quanto ao destino a ser dado aos embriões congelados. Enquanto a Igreja Católica considera o embrião um ser humano, cuja eliminação corresponderia à prática do aborto, o texto afirma que em muitos países confere-se ao embrião "personalidade jurídica" e direito à herança. ${ }^{11}$ A regulamentação vira notícia mais uma vez em 1994, em debates dos Institutos Nacionais de Saúde nos EUA, colocando-se a pergunta sobre a condição de um embrião humano do ponto de vista moral. Os aspectos práticos desse debate nos EUA referem-se à possibilidade de realizar experimentos com embriões, se é lícito formá-los para tanto ou se seria melhor usar os embriões que sobram dos tratamentos de fertilidade. ${ }^{12}$

A primeira notícia trata de uma medida legal que incide sobre o acesso aos procedimentos médicos e, portanto, restringe o tipo de pessoa que pode tornar-se pai ou mãe por meio do recurso à reprodução assistida, limitando a possibilidade de criação de laços de parentesco por essa via. A definição do estatuto do embrião tem conseqüências práticas, não apenas para o parentesco, mas também para procedimentos científicos e para a legalidade de práticas como o aborto. A ambigüidade da condição desse ente é perceptível na solução contraditória da legislação francesa que lhe nega o estatuto de pessoa, porém proíbe rigorosamente que seja material de experimentos. A análise de uma situação prática como a do caso seguinte pode revelar os termos e os atores desse debate em um contexto mais amplo do que o jurídico.

\section{A polêmica da destruição dos embriões congelados na Inglaterra}

No ano de 1996, a imprensa acompanha a polêmica sobre a destruição de embriões congelados na Inglaterra. O primeiro artigo apresenta o título "Destino de embriões humanos mobiliza a Grã-Bretanha: ovos humanos congelados devem ser destruídos se 'pais' não forem achados". ${ }^{13} \mathrm{~A}$ situação decorre de uma lei britânica que institui a destruição de embriões congelados por cinco anos, caso não seja solicitado o seu implante pelos pais, ou não haja a autorização destes para adoção por outros casais ou para uso em pesquisa. Uma associação em defesa da ética na reprodução sugere que "os abandonados sejam oferecidos aos casais sem filhos", mas a autoridade inglesa argumenta não haver "adoção possível sem a concordância dos progenitores naturais, que quase nunca se lembram de seus filhos congelados". A conclusão do artigo refere-se a "questões médicas e humanas" suscitadas, pois "um embrião cedido sem saber de quem é filho pode querer descobrir,

ANO $9392 \quad 2$ O SEMESTRE 2001 
14 "Vaticano é contra inseminação". O Dia. 18 mai. 1996. Geral, p.3.

15 "Embriōes humanos vão ser destruídos". Jornal do Brasil. 8 jul. 1996. Ciência, p. 12.

16 "Católicos condenam eliminação de embriões: casais britânicos propõem adoção e criam impasse ético". Jornal do Brasil. 23 jul. 1996. Ciência, p. 12

17 "Italianas vão adotar embriões". Jornal do Brasil. 27 jul. 1996. Ciência, p. 12.

18 "Embriōes humanos vão ser destruídos hoje: grupos próvida não conseguem adiar eliminação". Jornal do Brasil. 1 ago. 1996. Ciência, p. 12.

19 "Italianos são contra". Jornal do Brasil. 1 ago. 1996. Ciência, p. 12.

20 "Inglesa consegue adiar destruição de embriões na Justiça: caso é o único no país e representa importante precedente jurídico". O Globo. Rio de Janeiro, 3 ago. 1996. Ciência, p. 32 anos mais tarde, quem são seus pais". Embora o autor não entre explicitamente na discussão do estatuto de ser humano dos embriões, percebe-se que o modo de referir-se a eles reporta alusões à sua condição de sujeitos, de crianças, ao falar de seus "pais", de "adoção", de embriões como "filhos abandonados". Salienta-se o modo pelo qual o artigo se refere à destruição dos embriões: "Sua execução é realizada despejando-os em álcool". Execução é um termo cunhado para pessoas condenadas à morte - mais uma vez os embriões sendo representados como sujeito.

Outro artigo reporta a posição do Vaticano sobre a possibilidade de destruição dos embriões na Inglaterra - "um massacre pré-natal, assassinato em massa" - , incentivando voluntárias a adotarem os embriões ingleses. Condenando a produção de embriões in vitro e seu congelamento, a lgreja Católica sugere aos casais inférteis a alternativa da adoção ou do trabalho com crianças abandonadas. ${ }^{14}$ Notícias poucos dias antes do prazo final para a destruição relatam os esforços de hospitais e clínicas para contatar os "pais de proveta". Enquanto grupos pressionam para que se permita a adoção dos embriões por casais inférteis, especialistas consideram necessário o "consentimento dos pais verdadeiros". ${ }^{15}$ Um artigo seguinte, recapitulando a polêmica, reporta a opinião do diretor de uma clínica britânica pioneira em FIV de que os embriões devem ser mantidos congelados enquanto a mãe estiver viva. ${ }^{16}$ Teólogos do Vaticano apresentam uma opinião diferente em artigo posterior, elogiando o gesto das voluntárias à adoção de embriões, o que enfatiza "o valor da vida", mas observando que tal opção não estaria prevista nos documentos oficiais da Igreja. Destaca-se a lista de proibições apresentada pelos teólogos: produção de embriões "fora do processo natural", seu congelamento e implantação, a doação de óvulos e o aluguel de úteros. ${ }^{17} \mathrm{O}$ assunto também foi destaque no dia previsto para a destruição. Os grupos pró-vida (anti-aborto) não conseguiram a permissão para que os embriões fossem adotados "sem o consentimento dos responsáveis". ${ }^{18}$ Quanto aos casais italianos sem filhos voluntários para a adoção dos embriões, as clínicas de fertilidade alegaram só poder entregá-los aos "pais legítimos". A posição do Vaticano foi de que, nesse caso, a adoção pré-natal seria lícita como solução de emergência, visto a Igreja Católica se opor à fertilização artificial. ${ }^{19} \mathrm{O}$ modo de evitar a destruição dos embriões era o pedido por escrito de "pai e mãe biológicos", de modo que apenas uma mulher conseguiu adiar na Justiça a eliminação dos seus embriões sem ter o acordo do "pai" ${ }^{20}$

A polêmica inglesa repercute também entre os médicos brasileiros, que apóiam o procedimento britânico de dar aos pais "a palavra final sobre o destino dos embriões 
21 "País não tem lei para embriões: polêmica de ovos". Jornal do Brasil. 28 jul. 1996. Saúde, p. 24.

22 ZÁGARI, Maurício; TEICH Daniel Hessel. "Polêmica da destruição de embriões chega ao Brasil". O Globo. 4 ago. 1996. O Mundo, p. 5-7. congelados". O texto destaca a inexistência de legislação específica sobre o assunto no Brasil, havendo apenas diretrizes do Conselho Federal de Medicina (CFM) proibindo a destruição dos embriões. ${ }^{21}$ Outro artigo, refletindo sobre a polêmica da destruição de embriões no tocante à situação brasileira, coloca que a decisão sobre o destino dos embriões congelados é tomada entre pais e médicos, em contrato feito antes do procedimento de acordo com as normas do CFM. Um monge católico esclarece que, para a Igreja Católica, a fecundação artificial constitui "violação da lei natural". Isso não justificaria eliminar os embriões, pois, a partir do momento da fecundação, "já existe um indivíduo, que tem os mesmos direitos de um ser humano formado". Por fim, um médico brasileiro especialista em reprodução humana destaca três correntes propondo marcos distintos para o início da vida: a fecundação, o término da fase inicial da reprodução celular e o momento em que o embrião está no útero materno. Segundo o especialista, o principal argumento para o descarte de embriões diz respeito ao fato de que "isoladamente, sem o útero da mãe, a medicina não pode fazer nada com eles". ${ }^{22}$

Três pontos ficam claros na polêmica acima: o tratamento dos embriões como sujeitos em primeiro lugar. Segundo, enquanto sujeitos, esses embriões estão envolvidos em uma trama de parentesco: eles têm pais e são os pais que exercem a autoridade máxima sobre eles como em situação de crianças dependentes. Finalmente, a relação desses embriões com os pais é constituída pelo vínculo genético: não são quaisquer voluntários a pais adotivos que contam no caso de embriões congelados em laboratório, mas os fornecedores do material genético que gerou esses embriões. Salienta-se o fato de que, em toda essa polêmica, apenas um médico lembrou explicitamente que embriões isolados fora do útero materno não têm chance de se desenvolver como pessoa, colocando a qualidade de pessoa como algo construído na relação, em lugar de um estatuto atribuído a um ente fora de contexto.

\section{A custódia dos embriōes}

Os embriões são considerados entidades que não podem responder por si. O debate sobre custódia diz respeito a definir quem são os responsáveis por eles. Um dos exemplos é encontrado nos Estados Unidos, onde se levanta o problema do que fazer com os embriões excedentes armazenados, conforme o artigo "EUA têm 100 mil bebês congelados". A antevisão da pessoa no embrião já começa no título que os designa como "bebês". O enfoque do artigo está nas leis que obrigam os pais que procuraram métodos de fertilização

ANO $9394 \quad 2$ O SEMESTRE 2001 
${ }^{23}$ WELTMAN, Wladimir. "EUA têm 100 mil bebês congelados: americana gera dois filhos $e$ não sabe o que fazer com outros sete embriões congelados". O Dia. 19 fev. 1998. Ciência e Saúde, p. 3.

24 "Embriões candidatos a adoção". Jornal do Brasil. 9 dez. 1998. Ciência, p. 12.

${ }^{25}$ NOVAES e SALEM, 1995, p. 65-88. artificial a decidir o que fazer com "os bebês que não são gerados". Um casal que já gerou dois filhos com esses métodos se pergunta o que fazer com os demais embriões, "afinal, foram gerados com nossos óvulos e nosso esperma". Foi apresentado em Nova lorque um projeto de lei com intuito de formalizar a custódia dos embriões congelados em casos de morte, divórcio ou separação dos pais. "No caso de morte do pais, os embriões podem ser implantados na mãe, doados para pesquisa ou destruídos. Na morte da mãe, os pais têm permissão de implantá-los em outra mulher". ${ }^{23}$ Está clara a importância do vínculo dos embriões com os 'pais', todavia a redação do artigo deixa confusa a solução na morte da 'mãe'. A dúvida consiste em se apenas 'o pai' pode autorizar o implante em outra mulher após a morte da 'mãe', ou se é feita referência aos 'pais' que planejaram a criança como detendo a autoridade para implantar o embrião em outra mulher quando morre a 'mãe' doadora do óvulo. De qualquer forma, existe a possibilidade de que embriões gerados em vida dos fornecedores de material germinativo venham a ser implantados após a morte de um desses fornecedores. Infelizmente, o artigo não esclarece de que modo se resolveria a filiação legal nesse caso.

Ainda sobre os EUA, outro artigo de 1998 menciona a proposta feita por médicos de lançar um programa de adoção de embriões excedentes, evitando que os centros de reprodução humana tenham que destruir os "estoques". Avalia-se que muitos casais estariam dispostos a doar seus embrióes armazenados, enquanto outros com dificuldade para ter filhos estariam interessados na adoção. ${ }^{24}$ De modo geral, a discussão sobre custódia visa a definir um lugar social para esse ente a fim de inseri-lo em uma rede de relações, quer reconhecendo a preexistência de um parentesco decorrente dos laços genéticos com os doadores de material reprodutivo, quer criando tais relações a partir de sua adoção. Tal esforço decorre do pressuposto de que os óvulos fecundados são dotados de subjetividade, daí chamá-los de "bebês congelados", reconhecendo-se sua condição humana.

A definição do lugar social do embrião e de quem é responsável por ele é uma situação complexa que nem sempre vai tomar o vínculo genético com os fornecedores de material germinativo como atributo definidor do direito e guarda sobre óvulos fecundados. Compreendendo as novas tecnologias reprodutivas em termos de "medicalização da fecundação", Novaes e Salem ${ }^{25}$ assinalam o incremento do número e do tipo de participantes implicados na concepção do embrião com destaque para os representantes da biomedicina (médicos, biólogos). Analisam um caso ocorrido na França em que se negou a uma mulher que havia 
${ }^{26}$ BARBOSA, Paulo Roberto B. "Direito à vida". Jornal do Brasil. 14 nov. 1998. Opinião dos Leitores, p. 10.
${ }^{27}$ CONKLIN E MORGAN, 1996, p. 657-694. enviuvado durante o tratamento de fertilidade o direito de receber $o$ implante dos embriões, transferindo-se a guarda dos mesmos para o hospital. O embrião extracorporal estaria inserido em uma rede de relações que relativiza a autoridade que sua genitora (fornecedora de material germinativo) teria sobre ele caso estivesse grávida, pois esta depende dos médicos para a realização da FIVETE.

\section{O embrião como ser humano individual}

Já foi vista acima a preocupação de diversos setores sociais sobre a situação dos embriões congelados. O debate sobre os procedimentos lícitos quanto ao embrião diz respeito à afirmação ou à negação de seu estatuto como ser humano dotado de direitos. Para a definição desse estatuto, posições são justificadas a partir de atributos existentes no embrião. Encontram-se diversas manifestações de defesa do "direito à vida" desses seres:

Reconhecem o resultado imediato da fecundação, o zigoto, como um ser que irá crescer e se desenvolver. Adentra-se o mais íntimo do ser humano, invade-se sua privacidade formal e alteram-se suas definições de vida e características genéticas, por simples diletantismo ou exercício do saber. Ao mesmo tempo, entretanto, são capazes de destruí-lo, porque é 'somente uma célula'. Será que a compreensão do ser humano sobre ele próprio não transcende à forma ou ao invólucro em que ele é apresentado? Será, pois, necessário que características secundárias sejam exteriorizadas, para que se diga: 'Este é um ser humano', enquanto se reconhece que sua condição genética já o qualifica em suas características físicas e mentais futuras? ${ }^{26}$

Essa carta de um leitor mostra a perplexidade com as mudanças propiciadas pela ciência, que alteram "as definições de vida" do ser humano. O leitor defende que "uma célula", no caso o zigoto, já é um ser humano com a compreensão de que este "transcende à forma ou ao invólucro em que é apresentado". Na visão desse leitor a centralidade do estatuto de ser humano, estaria em "sua condição genética (que) já o qualifica em suas características físicas e mentais futuras" - ele critica a postura de que "características secundárias sejam exteriorizadas" antes que se defina um ente como ser humano. Nota-se aqui a visão de "natureza humana" sediada no código genético, base para a definição de pessoa humana a partir do momento em que se forma o zigoto, tendo então o "direito à vida". As observações do leitor coincidem com pesquisa feita por Conklin e Morgan sobre a construção social da pessoa do feto. ${ }^{27} \mathrm{Na}$ representação ocidental, os critérios para o estabelecimento da condição de pessoa residem na

ANO $9396 \quad 2$ O SEMESTRE 2001 
NAARA LUNA

28 "Vaticano defende que a ciência aceite o embrião como ser humano". Notícias do Vaticano http:// www.sm.conex.com.br/ bispado/tela 28.htm.

29 Denomina-se de préembrião a fase do desenvolvimento embrionário anterior ao surgimento da linha primitiva por volta do décimo quarto dia a contar da concepção, o que configuraria o início de sua individualização com o surgimento dos primórdios do sistema nervoso.

${ }^{30}$ CONKLIN E MORGAN, 1996, p. 664 .

${ }^{31}$ SPOLIDORO, Luiz Cláudio Amerise; MARTINS, Ives Gandra da Silva. "Doutrina nacional: posicionamento jurídico no crime de aborto". ITE - Revista Jurídica, n. 16. http:// www.ite.com.br/revista/ rev_16/rev_16_4.htm. biologia, sendo atribuídos a fatores não-sociais. Uma pessoa seria criada a partir de interação social mínima no ato sexual, este tornando-se até dispensável com o advento das novas tecnologias reprodutivas. Os genes são considerados marco da identidade biológica e singularidade do indivíduo.

Posição semelhante à adotada pelo leitor acima é a manifestada pelo Vaticano conforme declaração da assembléia geral da Pontífica Academia pela Vida, da qual participam biólogos, médicos, filósofos e juristas de vários países, veiculada na página da Internet "Notícias do Vaticano". ${ }^{28}$ A dignidade pessoal do embrião humano $e$, portanto, seu direito à vida e à integridade se depreendem da evidência do dado biológico e não exclusivamente de uma posição de fé, sendo tal posição tomada após contínua pesquisa científica. A Igreja Católica descarta concepções da teologia medieval, considerando que, do ponto de vista biológico, a formação e o desenvolvimento humano aparecem em um "processo contínuo, coordenado e gradual desde a fertilização, com o que se constitui um novo organismo dotado de capacidade intrínseca de desenvolverse autonomamente em um adulto". A partir dessas conclusões, rechaça-se a noção de pré-embrião ${ }^{29}$ como uma etapa de desenvolvimento em que o ser humano ainda não seria reconhecível, justificativa para autorizar experiências com embriões nesta fase. Pelo contrário, a lgreja propõe o reconhecimento da presença do ser humano com uma capacidade ativa e intrínseca de desenvolvimento desde a fertilização do óvulo. Autonomia e capacidade de desenvolvimento ativo são os pontos-chave da concepção de pessoa veiculada nesse pronunciamento. Tanto a carta do leitor acima como esse pronunciamento ligado à Igreja Católica explicitam aspectos da ideologia ocidental da pessoa, com ênfase no individualismo, no self egocentrado, na autonomia social, no autocontrole e na responsabilidade sobre si próprio. ${ }^{30}$

Já a noção de pessoa encontrada no artigo "Posicionamento jurídico no crime de aborto" veiculado pela Internet ${ }^{31}$ apresenta referenciais distintos da posição do Vaticano. Os autores estabelecem a divisão entre gravidez, período que vai da fecundação até o nascimento, e vida, período começado no nascimento e que vai até a morte. Antes do parto, o feto é um estado potencial de vida, ganhando a vida a partir do nascimento quando ocorre a autonomia biológica de mãe e filho, com dois corpos independentes. O artigo defende que, perante a lei, o produto da concepção é apenas um estado potencial, sendo o nascimento com vida a conexão que permite o ganho do atributo personalidade pelo produto da concepção. Ao feto sem vida não se reconhece 
${ }^{32}$ CONKLIN E MORGAN, 1996, p. 671. personalidade jurídica, um atributo da pessoa capaz de fazer gerar sua condição de sujeito de direitos. Se é o nascimento com vida o que confere o caráter civil de pessoa, o aborto não pode ser um crime contra a pessoa, apenas um crime impeditivo do nascimento. Segundo esse raciocínio, a tese jurídica de que a vida se inicia com a fecundação está equivocada, mesmo no caso de a concepção ocorrer fora do corpo da mulher, um raciocínio válido para a FIV e o congelamento de embrióes. Assim, os autores desse texto instituem outros marcos biológicos para a emergência da condição de pessoa, em particular, o nascimento, em vez da concepção, contrapondo-se à posição da Igreja.

O respeito à vida humana é o valor universalista que fundamenta a discussão ética sobre o aborto, sobre a condição de pessoa de óvulos fecundados dentro ou fora do corpo materno, sobre os parâmetros a serem estabelecidos no trato de fetos e embriões humanos que não chegaram a nascer. A maior parte dos argumentos envolvendo o estabelecimento de um estatuto para esses seres se baseia na fisicalidade, em sua natureza biológica. A discussão tenta definir um marco para a emergência da condição de pessoa em função de características biológicas: a base genética, a fertilização dos gametas, a emergência da linha primitiva ou outro ponto qualquer no desenvolvimento embrionário, o nascimento. A partir desse limite o estatuto de pessoa seria considerado inerente a esses seres, uma característica em si que não depende da relação desses seres com outros. Esse pensamento seria decorrente da concepção biomédica ocidental de corpo que considera o desenvolvimento do feto um processo biológico automático desencadeado no encontro dos gametas. ${ }^{32}$ Assim, a representação oculta de tal modo as relações a ponto de obscurecer a impossibilidade concreta de que, do óvulo fertilizado ao bebê, o desenvolvimento ocorra isoladamente, sem que relações envolvam os seres. A imagem apresentada para tal concepção de pessoa é a de indivíduo em interação com o meio, em lugar de outras concepções de pessoa segundo as quais as relações constituem as pessoas, as constroem.

Embora a tônica de vários textos analisados nesse item diga respeito aos direitos individuais do embrião, em expressões acima que o dotavam de subjetividade, estava clara a existência de laços de parentesco envolvendo este ser ("embriões órfãos", "embriões abandonados pelos pais", "pais de proveta", "filhos congelados", "consentimento dos pais verdadeiros"). Ambos os tipos de registro assinalariam $o$ que Strathern chama de contraste

ANO $9398 \quad 2^{\circ}$ SEMESTRE 2001 
NAARA LUNA

${ }^{33}$ STRATHERN, 1999b, p. 193198.

34 Como exemplos da reflexão antropológica sobre teorias de parentesco em função das novas tecnologias reprodutivas veja: STRATHERN, 1992; EDWARDS et al., 1999a.

${ }^{35}$ LUNA (2000) descreve como - campo da medicina de reprodução humana é constituído por um debate de diversos segmentos sociais com variados tipos de discurso incluindo os menos 'formais' ou 'sérios' (fofocas, humor).

${ }^{36}$ SCHNEIDER, 1968, p. 21-54. entre a representação do indivíduo abstrato em termos de uma entidade sem relações, 'flutuante solta' (free floating), característica do discurso universalizante, e a representação de indivíduos reais constituintes de uma rede de relações. Esse contraste seria próprio dos construtos de parentesco ocidentais nos quais a pessoa pode ser imaginada ora em termos de uma ente individual ora como um ente emaranhado em relações sociais. Há uma ênfase dual na singularidade da pessoa e em sua inserção em um campo de relacionamentos. $O$ parentesco ocidental teria maneiras relacionais e não-relacionais de pensar as pessoas. ${ }^{33}$ As várias referências aos laços de parentesco no debate sobre a condição do embrião sinalizam a importância do parentesco para a construção da pessoa mesmo em sua representação mais atomizada que é a de indivíduo.

\section{Parentesco e Natureza}

Após um período de menor ênfase em estudos sobre as relações de parentesco do Ocidente atual, o debate sobre as novas tecnologias reprodutivas estimulou o aumento da reflexão e pesquisa antropológica nessa área. ${ }^{34}$ Conforme se percebe pelas matérias da imprensa analisadas, não é somente entre cientistas sociais que as tecnologias de procriação provocam debate, sendo um tema presente na mídia que tem provocado diversos tipos de resposta entre 'Ieigos'. ${ }^{35}$ Tamanho interesse seria decorrente da representação nativa de parentesco presente entre os ocidentais.

As conclusões da análise simbólica do parentesco nos Estados Unidos feita por Schneider foram adotadas na Antropologia mais recente para compreender alguns traços gerais do parentesco ocidental. ${ }^{36}$ Tal concepção caracteriza-se por dois aspectos básicos: o primeiro consiste na conexão entre parentes por meio de substância biogenética comum, os 'laços de sangue' irrevogáveis. $O$ segundo aspecto é o vínculo estabelecido pelo código de conduta, o complexo de atitudes que caracteriza a relação de intimidade entre os parentes. Nas relações entre parentes mais próximos ambos os aspectos estariam presentes. Entre pais e filhos seriam encontrados os 'laços de sangue' e a conduta característica que rege o relacionamento de pais e filhos. Já os parentes por afinidade seriam ligados apenas pelo código de conduta. Dessa forma, o parentesco como conexão de substância consistiria em um vínculo material e irrevogável, enquanto o parentesco na qualidade de código de conduta seria um laço subjetivo decorrente de convenções sociais, portanto mais sujeito a alterações. Pai e mãe contribuem igualmente em termos de substância para 
${ }^{37}$ STRATHERN, 1992, p. $18-20$.

${ }^{38}$ STRATHERN, 1992 a formação dos filhos. O amor seria o símbolo de unidade do parentesco, relacionando os aspectos de comunhão de substância e de código de conduta. A relação sexual dos cônjuges assinala o amor entre eles. Essa dimensão erótica deve estar ausente no amor existente entre os cognatos, isto é, entre pais e filhos, bem como entre irmãos. Schneider arrisca a hipótese de que a descoberta pela ciência de novos fatos quanto à relação biogenética pode propiciar mudanças na concepção ocidental de parentesco. As duas dimensões de parentesco correspondem na cosmologia ocidental à oposição entre natureza, fundamento da realidade, e cultura, criação humana a partir da base natural. A análise de Schneider já apontaria para o impacto das novas tecnologias reprodutivas na concepção ocidental de parentesco por promoverem a reprodução sem a relação sexual, símbolo de amor, bem como por tais procedimentos interferirem no processo de formação dos vínculos de substância.

Segundo Strathern, o laço de substância, tido como proveniente da natureza, foi biologizado no decorrer do século XX. Com o recurso às novas tecnologias reprodutivas, veio a se introduzir ambigüidade no parentesco. Este deixa de ser considerado um domínio distinto quando as técnicas médicas interferem na natureza, e a legislação afeta os arranjos sociais, desestabilizando os laços naturais, antes considerados irrevogáveis. ${ }^{37}$ As tecnologias de procriação propiciam a fragmentação do papel materno, como no exemplo da mãe substituta, evidenciando a descontinuidade entre a construção social do papel materno e o fato natural. O processo reprodutivo também é fragmentado em séries de etapas descontínuas, desmontando o processo único e contínuo de ser mãe no caso da maternidade substituta. A mãe é uma combinação assimétrica de funções naturais e sociais referentes aos papéis desdobrados em: formação, dar à luz e cuidado com a criança. Com o advento das novas tecnologias reprodutivas, falta clareza na definição da relação social a partir do nexo biológico, porque nenhum dos fatos, como a doação de material reprodutivo, a disponibilização do útero para a gestação e o aleitamento, por si mesmo garante a conexão enquanto relacionamento. Parte do papel da gestação antes considerado biológico passou a ser visto como social. ${ }^{38} \mathrm{O}$ recurso à fertilização in vitro possibilita duas formas de corporificação, implicando dois tipos de maternidade: a da mãe gestacional ou substituta, que leva a gravidez a termo, e a da mãe genética, participante da identidade genética do filho, tal diferença sendo comparável à existente entre pai e mãe. Além dessa diferença na corporificação da maternidade, deve-se ter em mente o papel da convenção social em estabelecer 
NAARA LUNA

${ }^{39}$ STRATHERN, 1991, p. 25-43.

40 STRATHERN, 1998, p. $182-$ 209.

${ }^{41}$ CALLIOLI, 1988, p. 73.

${ }^{42}$ RIZZARDO, 1991, p. 74.

${ }^{43}$ STRATHERN, 1992, p. $122-$ 125.

${ }^{44} \mathrm{TEICH}$, Daniel Hessel. "A reinvenção da vida: médicos realizam $O$ sonho de paternidade para homens que não produzem espermatozóides". O Globo. 24 dez. 1995. Jornal da Família, p. 1. que vínculos biológicos contam para definir a mãe. Convenciona-se que uma mulher é a mãe se um embrião for implantado nela para solucionar sua própria infertilidade, mas não será considerada mãe se sua gestação for em favor de outra. ${ }^{39}$ As novas tecnologias reprodutivas salientaram o componente biológico do parentesco ocidental, impondo uma compreensão de biologia mediada tecnologicamente. ${ }^{40}$

As novas tecnologias reprodutivas, em particular a fertilização in vitro, implicam a representação de afastamento do embrião em relação à sua mãe conforme se evidencia em dois artigos jurídicos debatendo a reprodução assistida: "O zigoto é uma vida humana (...) independente do meio que o rodeia e com a potencialidade necessária para dar lugar a um ser humano adulto". ${ }^{41}$ "A nova vida humana que surge constitui um indivíduo humano separado e distinto do pai e da mãe (...) que possui todo o necessário para organizar o próprio desenvolvimento, seu crescimento e sua diferenciação, num ambiente apropriado. A ambientação biológica num lugar natural ou artificial é uma circunstância acidental." 42 Sendo o embrião extracorporal equiparado a um indivíduo, apaga-se cada vez mais a figura da mãe durante a gestação, encarada como um meio, um ambiente, um lugar circunstancial, em vez de um outro ser humano com quem se estabelecem relações. Segundo Strathern, o fato de a sociedade ser igualada a um ambiente na representação ocidental permite que se pensem as pessoas estando em relação com a sociedade em vez de se relacionarem com outras pessoas. As relações não seriam integrais à condição de pessoa, mas formam-se depois desta. $^{43}$

A micromanipulação de gametas tem sido uma grande inovação das novas tecnologias reprodutivas, em particular a ICSI ou injeção intracitoplasmática de espermatozóide. A técnica é indicada para os casos de baixa produção ou má qualidade do esperma, quando os espermatozóides não conseguem penetrar no óvulo, injetando-se um deles diretamente no citoplasma. Muitos homens que estariam na faixa da infertilidade podem fertilizar óvulos por meio do método, dispensando a doação de esperma. Nesse sentido, vem a expressão na matéria descrevendo esse procedimento: "nada de pai desconhecido". ${ }^{44}$ Esse tipo de tratamento reforça o aspecto genético da parentalidade, a comunhão de substância no parentesco. O outro aspecto do parentesco que se contrapõe e complementa este é o código de conduta. Existe a possibilidade de que nenhum dos pais tenha vínculo genético ou de substância qualquer com a criança, o vínculo se dando pelo planejamento do filho. A parentalidade volta- 
45 "Bebês de proveta têm pais melhores". Jornal do Brasil. 3 abr. 1995. Ciência, p. 6.

\footnotetext{
${ }^{46}$ As normas aprovadas pelo Colégio Italiano de Medicina em 1995 para regulamentar a reprodução assistida proibiram todas essas alternativas mencionadas. Veja: "Itália limita fecundação artificial". "Lésbicas e mulheres com mais de 50 anos sofreram restrições". O Globo. 14 abr. 1995. Ciência, p. 17. Outros exemplos 'escandalosos': "Nunca é tarde: britânicos criticam médico que fez mulher de 59 anos dar à luz". Isto É. 5 jan. 1994. p. 18; "Geração reprovada: Papa condena inseminação em lésbicas". Isto É. 29 jun. 1994. p. 18; "Inglesa pode usar esperma de morto". Jornal do Brasil. 7 fev. 1997. Ciência. p. 5; "Banco de sêmen ajuda solteiros de Israel a ter filhos: gays e mulheres heterossexuais formam público-alvo de centro". $O$ Globo. 16 fev. 1996. Mundo, p. 26.

${ }^{47} \mathrm{HIRSCH}, 1999$, p. 93.

${ }^{48}$ SCHNEIDER, 1968, p. 50.
}

se para a intencionalidade, tendo por referente a intenção de paternidade em detrimento da existência de vínculos genéticos. Enfatizando esse aspecto percebido como construído do parentesco, um estudo realizado em Londres mostra que casais que tiveram seus filhos por meio da FIV são pais melhores, pois se dedicam mais aos filhos. $O$ resultado mostraria que "laços genéticos" teriam menos importância do que o "forte desejo pela paternidade". ${ }^{45}$ As novas tecnologias reprodutivas, por meio da doação de gametas e da maternidade substituta, tanto podem reforçar os dados ditos naturais de parentesco como relativizá-los, evidenciando seu o caráter construído.

A possibilidade de interferir no modo dito natural de realizar a reprodução humana, constituindo o parentesco, nem sempre encontra aceitação social. Percebe-se reticência em facultar $o$ acesso à reprodução assistida no contexto de casos considerados escandalosos: mulheres sem parceiro, mulheres na menopausa (mães-avós), casais de lésbicas, pessoas que querem usar os gametas de parceiro já morto (IA e FIV póstumas). ${ }^{46}$ Essa reticência pode ter dois aspectos: o primeiro é uma tentativa de pautar os tratamentos oferecidos em "regras" ou "leis" existentes na própria natureza, isto é, a tecnologia pode aperfeiçoar a natureza, desde que as mudanças sejam fiéis a princípios pressupostos da natureza. ${ }^{47}$ Mulheres não se reproduzem sozinhas, tampouco as que atingiram a menopausa, pois param de ovular; uma mulher não engravida outra; pessoas mortas não têm mais capacidade reprodutiva. A disponibilização dos gametas fora do corpo, as técnicas para sua conservação, bem como o acesso a células germinativas de doadores, possibilitariam tecnicamente a reprodução em todos os casos acima. A violação de "leis da natureza", contudo, não é o único aspecto que causa mal-estar nessas possibilidades. Os casos polêmicos acima têm como ponto comum ameaçarem a existência das relações. O uso das técnicas de reprodução assistida costuma ser bem visto quando o casal heterossexual não consegue engravidar por meio da via "natural" das relações sexuais. $O$ ato sexual não é considerado apenas uma atividade procriativa, mas também consiste em símbolo de relação. A família no ideário ocidental é paradigma do modo de conduzir as relações de parentesco, tratando-se de relações de amor, de solidariedade difusa e duradoura. ${ }^{48}$ Os casos acima colocariam em risco a existência dessa família. No exemplo do casal de lésbicas, o risco estaria dado no novo arranjo familiar com o par homossexual. Já nos demais casos, percebe-se a própria relação como posta em xeque. Mulheres que buscam a gravidez na menopausa, após o término de seu período fértil, são constantemente acusadas de irresponsabilidade, uma vez que o filho gerado

ANO $9402 \quad 2$ O SEMESTRE 2001 
NAARA LUNA

${ }^{49}$ STRATHERN, Marilyn, 1995a, p. 303-329. corre risco de cedo tornar-se órfão dada a idade avançada de sua mãe, com a relação mãe-filho logo se extinguindo. Por fim, no caso da mulher inseminada com o esperma do parceiro já morto ou de embrião implantado em outra mulher após a morte da mãe genética, a morte já representa o término das relações do casal. A mulher que deseja engravidar sem parceiro usando o tratamento médico em lugar da relação sexual seria mais um exemplo de se negar a relação de parceria do casal.

Strathern analisa um fenômeno semelhante que pode auxiliar a refletir sobre a importância da relação para efetivar o parentesco. ${ }^{49} \mathrm{Na}$ Inglaterra, o caso de mulheres sem experiência sexual nem intenção de tê-la que procuravam clínicas de fertilidade com o intuito de receberem 0 tratamento de inseminação artificial por doador e engravidarem foi designado pelos meios de comunicação de "síndrome do nascimento virgem". A atitude dessas mulheres foi encarada com reservas por alguns médicos, colocando-se em pauta que tipo de pessoa seria apta ao tratamento. O tratamento visava a substituir a relação sexual em vez de simplesmente contornar um estado estéril, superando dificuldades da natureza. O especialista em reprodução humana acabaria por ser o único parceiro da mulher no ato reprodutivo, embora realizado em laboratório. A presença do pai seria intencionalmente excluída da concepção da criança. Tal postura contraria os papéis de gênero estabelecidos, segundo os quais as mulheres seriam as guardiãs do ideal de que filhos nascem de relações de parceria, relações essas constituindo o alicerce da vida familiar. De fato, até o advento dos exames de DNA, o pai de uma criança só era identificável a partir do seu relacionamento com a mãe. Este é um dos motivos para se perceber a procura intencional de concepção sem 0 ato sexual em termos de recusa de relacionamentos. A "síndrome do nascimento virgem" indicaria que não basta ter um embrião implantado em si para tornar uma mulher mãe, sendo importante também o ato sexual para defini-la. Essa percepção seria decorrente das idéias ocidentais de parentesco que colocam uma fisiologia da reprodução anterior às relações entre as pessoas. Nesse sistema, enquanto a reprodução biológica se desenrola automaticamente, os relacionamentos teriam que ser construídos posteriormente. O filho nasce em forma de indivíduo, necessitando depois ser dotado de relacionamentos. A atitude das 'candidatas virgens à maternidade' por meio da reprodução assistida gera tanta controvérsia por ser percebida como a negação dos relacionamentos necessários para a constituição do parentesco e da família dessa criança. 
50 "Mãe americana gera gêmeos de seu próprio filho". O Globo. 23 fev. 1996. O Mundo, p. 25.

${ }^{51}$ A inspiração para falar de incesto nesses termos veio da pesquisa etnográfica de Janette Edwards sobre as representações do impacto das tecnologias reprodutivas. Ela constata o surgimento de idéias referentes a incesto na eventualidade de haver doação de gametas de filha para mãe ou união de gametas de irmão e irmã no caso de doação anônima. EDWARDS, 1999, p. 73.

${ }^{52}$ STRATHERN, 1999b, p. 177.
O recurso aos procedimentos das tecnologias de procriação pode gerar situações de confusão nas relações de parentesco. Um exemplo nos Estados Unidos está no caso da mulher que serve de mãe substituta para a nora, gestando os filhos do próprio filho, isto é, seus netos. Ao nascerem os gêmeos, o nome da mulher que deu à luz deverá constar na certidão de nascimento; por outro lado, o filho dela, pai genético dos bebês, não poderá registrá-los como seus. 0 filho e a nora da gestante, pai e mãe genéticos, terão que entrar em processo de adoção das crianças. Finalmente, 0 próprio texto faz a ressalva de que os pais genéticos dos bebês não são parentes, por isso as crianças "não correm risco de sofrer deformações genéticas, que podem acometer crianças geradas de relações incestuosas ou entre parentes próximos"..$^{50}$ Embora o texto noticie sobre outras mulheres dando à luz bebês gerados com óvulos de suas filhas, o fato de o pai genético ser filho da gestante sugere mais claramente um caráter incestuoso nesses vínculos. ${ }^{51}$ Daí a necessidade de ressalva no próprio texto jornalístico, reduzindo incesto à união do material genético de parentes muito próximos. No caso, o incesto não se configuraria na existência de ato sexual entre parentes consangüíneos de primeiro grau, mas pela confusão das relações de filiação, como fica explícito pela impossibilidade legal de o pai genético registrar como seus os filhos nascidos da própria mãe. Strathern adverte para essa representação de incesto referente às conseqüências da combinação de substâncias que posiciona doadores de material reprodutivo tal qual parceiros sexuais incestuosos. ${ }^{52}$ Compreendo aqui o incesto nesse sentido mais amplo, envolvendo a transgressão de limites nas relações de parentesco e não somente $o$ ato sexual. Creio que diversas polêmicas nas quais se apresentam as novas tecnologias reprodutivas na qualidade de ruptura de limites ditos naturais assumem o caráter de escândalo por insinuarem relações incestuosas de parentesco, a falta de nitidez nos papéis e a mistura de elementos proibidos, até mesmo de espécies animais diferentes. A seguir, serão analisados três grupos de notícias destacadas a partir do grau de escândalo despertado pela violação do que se concebe por regras da natureza, isto é, da confusão, mistura e transgressão de limites que implicam.

\section{Trocas e misturas de substância}

No primeiro grupo, as polêmicas surgem a partir da revelação de trocas e misturas indevidas de material reprodutivo. Uma matéria denuncia a implantação de embriões trocados em mulheres na Inglaterra. Desta forma, muitas mulheres haviam "educado o filho de outra" sem saber. 
NAARA LUNA

53 "Jornal inglês denuncia troca de embriões em laboratório". O Globo. 21 nov. 1994 b. O Mundo, p. 15.

54 "Centros fazem troca de sêmen na ltália". O Globo. 23 jan. 1995. 10 Caderno, p 12.

${ }_{55}$ BOURRIER, Any "Pais de gêmeos temem a discriminação social". Jornal do Brasil. 19 jun. 1995. Ciência, p. 4.

${ }^{56}$ BOURRIER, Any. "Holandesa dá à luz gêmeos de duas raças: erro médico na fecundação 'in vitro' deixa pais abalados e causa confusão na França". Jornal do Brasil. 18 abr. 1996. Ciência, p. 12.

57 "Negra será fecundada por óvulo de branca". Jornal do Brasil. 26 jan. 1994. Ciência, p. 12
Uma das mulheres, quando informada de que Ihe haviam implantado o embriáo de outro casal, pediu que o retirassem imediatamente "porque não suportava a idéia de ter dentro de mim (si) o filho de outra". O testemunho dessa mulher revela também a importância do vínculo criado pela gestação contraposto à idéia de "filhos trocados" sugerida pelo texto. ${ }^{53} \mathrm{Na}$ ltália, teria ocorrido uma situação semelhante em que centros de inseminação artificial, a fim de conseguir bons resultados, trocavam o sêmen de homens com problemas de fertilidade pelo de doadores a fim de permitir a fecundação, sem que os primeiros tivessem conhecimento. A notícia destaca que muitos estão criando filhos "que acreditam ser do casal, mas que são, na verdade, de um estranho". ${ }^{54}$ Outro escândalo ocorreu quando uma mulher submetida a tratamento de FIV gerou gêmeos de "raças" diferentes devido à negligência na esterilização do material, o que permitiu que o sêmen do marido se misturasse ao de outro paciente. ${ }^{55} \mathrm{~A}$ mulher teria afirmado que dar à luz $\mathrm{o}$ filho de um homem que não era seu marido provocava-lhe a sensação de ter sido estuprada. ${ }^{56} \mathrm{O}$ último caso que provocou polêmica foi a implantação de óvulo de mulher branca em uma negra. Justificou-se o procedimento porque a mulher esperava há quatro anos uma doadora negra sem conseguir. Além disso, sendo a paciente casada com um mulato que forneceu o esperma, a criança gerada seria "de raça mista" de qualquer modo. Comparou-se também este fato com a decisão de uma mulher negra casada com um branco na Itália de usar óvulo de doadora branca na FIV a fim de evitar que seu filho sofresse racismo. ${ }^{57}$

Relações raciais fazem parte do quadro das notícias de mulheres negras recebendo óvulos de doadoras brancas como também da geração de gêmeos de "raças" diferentes em uma mesma mulher por causa da mistura de esperma. A diferença está no conhecimento e consentimento para que as operações se realizassem. Da mesma forma, a troca de embriões, a troca de sêmen e a mistura do sêmen ocorreram sem o conhecimento nem o consentimento dos pacientes de reprodução assistida. Nesses três casos, erros médicos implicaram a interferência na constituição do parentesco genético do casal, envolvendo um terceiro elemento na comunhão de substância. No exemplo da troca de embriões, o próprio embrião era estranho, já na troca e na mistura de sêmen um genitor masculino desconhecido interferia na relação do casal e particularmente na comunhão de substância do pai com o filho. Interessante é a ênfase no relato jornalístico das três notícias de que os casais estariam criando filhos de outros. A interferência na comunhão de substância entre pais e filhos só deveria ser 
${ }^{58}$ SALEM, 1995, p. 33-68.

59 SILVA, Mário Andrada e. “'Pais póstumos' nos EUA causam polêmica". Jornal do Brasil. 31 mai. 1997. Internacional, p. 10.
60 "Menina italiana nasceu dois anos após a morte da mãe". O Globo. 11 jan. 1995. O Mundo, p. 20. "Nascimento de Elisabetta cria polêmica". Jornal do Brasil. 14 jan. 1995. Ciência, p. 6.

61 "Bebê de mãe morta escandaliza Vaticano". Folha de S. Paulo. 12 jan. 1995. Ciência, p. 1,16. permitida com o conhecimento e consentimento de ambos os pais, como na doação de gametas. O dilema das referidas mulheres negras não é o de receberem a doação de óvulos, mas o fato de a doadora ser incompatível com sua aparência, desrespeitando a regra na doação de gametas de proporcionar doadores parecidos fisicamente com os pais $^{58}$ a fim de que o tratamento médico, na construção desse parentesco, se assemelhe a resultados que seriam obtidos 'naturalmente'. Salem chama de manipulação social das origens genéticas a tentativa de compatibilizar as características do doador com as do casal infértil, tentando naturalizar os laços socialmente estabelecidos por meio da mimetização do biológico. Esse tipo de procedimento facilita o segredo muitas vezes envolvido nos tratamentos de reprodução assistida e na adoção.

\section{Reprodução póstuma}

A inseminação artificial e a fertilização in vitro póstumas também despertam bastante polêmica. Um exemplo clássico diz respeito à retirada de esperma de homens mortos a pedido de suas famílias nos EUA. Tal debate ético estaria relacionado ao "campo da fertilidade e da morte". O centro do debate seria a necessidade de consentimento prévio do doador para a retirada, contraposta à autoridade da família. A dúvida consiste em se a retirada de esperma pode ser tratada como um caso de doação de órgãos. ${ }^{59} \mathrm{Em}$ contraste com órgãos doados de pessoas falecidas, o material germinativo tem a potencialidade de gerar novas pessoas, uma faculdade inexistente para mortos. As reações despertadas em situações com a formação de parentesco com vínculo de substância biogenética após a morte de um 'genitor' (doador de material reprodutivo) merecem mais reflexão.

Um dos casos mais controversos ocorreu na ltália com uma menina nascida a partir de um embrião implantado em sua tia, irmã de sua mãe genética, dois anos após a morte desta mãe. O embrião foi implantado a pedido do pai genético da menina. ${ }^{60} \mathrm{Um}$ terceiro artigo ressalta que, do ponto de vista legal, a menina é filha de sua tia (mãe substituta) e de seu tio, todavia, segundo a lei italiana, o pai legal tem o prazo de um ano para retirar a paternidade, enquanto a mãe legal tem o prazo de seis meses. Por fim, o pai biológico pode pedir a impugnação do reconhecimento da paternidade legal a qualquer momento. Uma psicanalista prevê dificuldades para a menina quando "for revelada a verdade sobre a sua origem". ${ }^{61}$ As representações de parentesco mencionadas nesse exemplo confirmam a tipologia apresentada por Schneider, opondo o laço 
NAARA LUNA

62 FRANKLIN, 1999, p. 134.

63 "Inseminação de óvulo de feto abortado gera discussão ética: críticos denunciam 'enfoque consumista' da criação da vida". Jornal do Brasil. 4 jan. 1994. p. 7.

64 "Governo britânico proíbe uso de óvulos de fetos abortados: controle das clínicas que realizam 0 tratamento será severo". Jornal do Brasil. 5 jan. 1994. p. 7. "Barreira ética: Londres proíbe o uso de óvulos extraídos de fetos abortados". Isto É. 12 jan. 1994. p. 16. fundamental de comunhão de substância biogenética ao laço socialmente construído da lei. As diferenças entre parentesco legal e genético ficam bem explícitas, não estando evidente ainda qual prevalecerá. De qualquer forma, a base do parentesco, considerada genética, pode fazer revogar seu aspecto legal. $O$ texto mostra ainda que $o$ parentesco tem um aspecto de origem a ser revelada, no sentido de uma verdade essencial sobre si que a pessoa necessita conhecer. Essa questão está presente no debate gerado no parlamento inglês quanto à regra do anonimato do doador de gametas. $O$ anonimato cercearia o direito de a criança conhecer suas origens genéticas, considerado essencial para "seu desenvolvimento bem-sucedido e aquisição de uma identidade completa". ${ }^{62}$ Uma teia de parentesco tão ambígua conforme a da menina italiana parece dificultar esse reconhecimento de si.

No ano de 1994, outras polêmicas se sucederam na Inglaterra no contexto da dificuldade de conseguir doadoras de óvulos para os tratamentos de infertilidade. A primeira polêmica se referiu à aprovação do método de uso de óvulos de fetos abortados na fertilização in vitro, o que geraria "filhos de mulheres que não chegaram a nascer". ${ }^{33}$ Militantes de organizações anti-aborto questionaram o que uma criança iria pensar ao saber que "sua mãe nem sequer nascera". A justificativa do procedimento estava em atender "o desespero de casais inférteis", mas um jornal britânico previu que a adoção do método fomentaria o surgimento de "uma fazenda de fetos, onde mulheres iriam engravidar, abortar $e$ vender os fetos". Em função da polêmica, logo em seguida o governo britânico tomou a iniciativa de proibir o uso de óvulos de fetos abortados, prometendo controle rigoroso sobre as clínicas. ${ }^{64}$ Os três artigos que noticiaram o fato apontaram para questões éticas como sendo o principal obstáculo para o tratamento, todos repetindo expressões do gênero "gerar filhos de mulheres que não chegaram a nascer". O primeiro aspecto da objeção levantada é a identificação da mãe de crianças nascidas por meio de tal tratamento com os fornecedores de material genético, no caso, os fetos abortados. Tal nexo de substância genética teria mais peso do que a relação com a mãe que gestaria o bebê. $O$ segundo ponto é que tal interpretação confere o estatuto de sujeito ao feto abortado. Mesmo sem ter nascido, sem ter alcançado plenamente a condição de pessoa viva, o feto poderia tornar-se mãe, na qualidade de fornecedor de substância germinativa.

Seis meses depois surge, na Associação Médica Britânica, a proposta do uso de óvulos retirados dos ovários de doadoras mortas. A matéria tem o sugestivo título de "Reanimator II", evocando um filme de terror. A opinião 
65 "Reanimator II: britânicos querem inseminar óvulos de mulheres mortas". Isto É. 13 jul. 1994.

66 "Inglês não pode utilizar óvulo de feto abortado". Jornal do Brasil. 21 jul. 1994. Ciência, p. 9.

${ }^{67}$ KOLATA, Gina. "Transplante de espermatozóide é possível". O Globo. 31 maio 1996. O Mundo, p. 34.

68 "Homem ou rato? 05/fev/98 São Paulo". Programe-se na virada do século -http:// www l.agestado.com.br/ 2000/ratos.htm. pública britânica estaria indignada com a possibilidade de "uma criança ser concebida com os genes de uma mulher morta". ${ }^{65}$ Logo em seguida, a autoridade britânica responsável por fertilidade e embriologia humanas restringe o uso de óvulos e tecidos ovarianos de fetos abortados e de cadáveres à pesquisa. Nos tratamentos de infertilidade, deverão ser usados apenas óvulos provenientes de doadoras vivas. Um dos motivos para a restrição são as conseqüências para as crianças geradas por esse tratamento caso venham a conhecer a sua origem. ${ }^{66}$ Está implícito o raciocínio da pequena importância da procedência dos óvulos destinados à pesquisa, uma vez que estes não gerarão seres humanos, em contraste com a preocupação manifesta quanto à origem dos óvulos que gerarão bebês. Seria um direito ou necessidade humana o conhecimento dessa origem referente também ao parentesco. Volto aqui ao problema do incesto, ou melhor, das origens espúrias: óvulos provenientes de 'não-seres', isto é, de cadáveres anônimos ou de criaturas que não chegaram a nascer.

\section{Identidade e mistura}

O último grupo de textos aborda questões de mistura e identidade. A primeira notícia trata de um novo tratamento para a esterilidade masculina. Células produtoras de espermatozóides poderiam ser transplantadas de um macho de determinada espécie para um macho de outra espécie, sendo cultivadas e multiplicadas naquele organismo, e posteriormente reimplantadas no macho da espécie original. A experiência teve resultados positivos no transplante de ratos para camundongos, mas na espécie humana a aplicação poderá permitir que um dia animais sejam usados para perpetuar a produção de espermatozóides de homens. Possibilitaria inclusive a reprodução após a morte, com o implante de células produtoras de espermatozóides de um homem já morto para cultivo em animais. Ao contrário do esperma congelado, que se esgota com o uso, a produção de esperma a partir dessas células poderia ser talvez inesgotável. O artigo traz a interpretação de que "a experiência quebrou uma das barreiras da biologia, mostrando que é possível superar algumas das diferenças entre as espécies". ${ }^{67}$ Posteriormente, uma revista científica publicou a proposta de transplante das células produtoras de espermatozóides de homens estéreis para ratos. Uma reflexão de título - "Homem ou rato?" - foi veiculada em 1998 na Internet pela agência de notícias do jornal O Estado de S. Paulo, reportando alguns pontos da proposta e levantando questionamentos éticos. ${ }^{68}$ Segundo o texto, a própria publicação científica reconhecia como problemas 
${ }^{69}$ DOUGLAS, 1976.

\footnotetext{
70 Embora a clonagem de adultos humanos a princípio não fizesse parte de meu recorte quanto às novas tecnologias reprodutivas, a postura de especialistas em infertilidade de aplicá-la a pessoas estéreis para que se 'reproduzam' impôs sua inclusão neste trabalho. WEISS, Rick. "Americano quer clonar humanos: pesquisador de Chicago afirmou que já tem equipe pronta e casais voluntários para realizar operação, permitida pela lei americana. Jornal do Brasil. 8 jan. 1998. Ciência, p. 10.

${ }^{71}$ WEISS, Rick. "Técnica cria embrião que tem duas mães: procedimento similar à clonagem combina óvulos de mulheres diferentes". Jornal do Brasil. 10 out. 1998. Ciência, p. 14.
}

para o procedimento o chamado "fator nojo", a aversão instantânea provocada pela idéia. Outros problemas seriam a possibilidade de contaminação do esperma humano com vírus existentes no camundongo e possíveis alterações no esperma humano devido ao ambiente de sua produção. A principal objeção levantada pelo autor do segundo artigo seria a perspectiva da biotecnologia de tratar seres vivos como "verdadeiras usinas e máquinas químicas". Esse autor critica o uso instrumental que a biotecnologia faria dos seres vivos, sem respeitar sua integridade. Todavia o principal elemento para escândalo em tal experiência seria violar a lei da natureza pressuposta que impede a mistura das espécies. Compreende-se desta forma o chamado "fator nojo" que a proposta desperta. Tanto as idéias sobre contaminação quanto o "nojo" remetem à análise de Mary Douglas sobre pureza e poluição, envolvendo um sistema de ordenação e classificação das coisas. ${ }^{69}$ A obtenção de ordem relaciona-se à rejeição de elementos inapropriados. A experiência de cultivar tecidos produtores de espermatozóides humanos em ratos, ao realizar a mistura, implica não apenas a desordem da classificação sistemática de espécies animais, mas também um desequilíbrio da ordem cara à cosmovisão ocidental que opõe estes aos seres humanos.

O caso seguinte é a proposta de clonagem de seres humanos adultos por um pesquisador na área de fertilização artificial. Os primeiros voluntários para o procedimento são estéreis, de forma que a clonagem constitui "a única maneira que eles têm para perpetuar seus genes" segundo o pesquisador. ${ }^{70}$ Destaca-se a justificativa apresentada para a clonagem de adultos como meio possível para transmissão de genes. A transmissão de genes também é o intuito da técnica de transferência nuclear. O núcleo do óvulo de uma mulher é transferido para o óvulo de outra cujo núcleo foi retirado previamente. O óvulo resultante dessa fusão é submetido à fertilização in vitro. O tratamento beneficiaria mulheres que produzem óvulos com citoplasma defeituoso, podendo então transmitir seu material genético. O problema ético no caso é a existência de DNA residual no citoplasma do óvulo, especificamente nas mitocôndrias, de modo que o embrião gerado teria duas mães genéticas. Um especialista em bioética comenta que essa possibilidade "levanta questões sobre laços de sangue e o significado do parentesco" para a criança gerada e a família. ${ }^{71}$ Nas três técnicas apresentadas acima, a justificativa reside na transmissão do material genético de uma pessoa estéril, reduzindo a isso o parentesco e a reprodução humana. Se o cultivo de espermatozóides humanos em outra espécie sugere mistura, a clonagem de seres humanos adultos alude 
${ }^{72}$ Este artigo já havia sido submetido para publicação quando surgiram notícias sobre o nascimento de crianças com duas mães genéticas a partir da técnica de transferência ooplásmica. Nesta técnica, transfere-se $10 \%$ do citoplasma do óvulo de uma doadora para o óvulo de uma mulher infértil. Testes genéticos constataram que as crianças nascidas herdaram genes do DNA mitocondrial da doadora. "Nascem os primeiros bebês com DNA alterado: crianças geradas por um pai e duas mães biológicas rompem limites da modificação genética do ser humano". O Globo. 5 mai. 2001. O Mundo/ Ciência e Vida, p. 35.

${ }^{73}$ VERÍSSIMO, Luís Fernando. "O chinês". Jornal do Brasil. 11 jan. 1998. Revista de Domingo, s.p.

${ }^{74}$ STRATHERN, 1999b, p. 212

ANO $9410 \quad 2^{\circ}$ SEMESTRE 2001 à perpetuação da identidade, enquanto a combinação de óvulos de duas mulheres diferentes resultaria em maternidade genética dupla, mistura genética das mães e incerteza da identidade para a criança que nascesse..$^{72}$

Uma crônica de Luís Fernando Veríssimo retrata a perplexidade existente diante da interferência nos processos da natureza. Na estória, cinco homens estão na ante-sala de uma maternidade aguardando suas mulheres darem à luz, quando um alerta que o filho de um deles nasceria chinês, segundo a estatística que de cada 5 bebês nascidos um era chinês. Quando alguém tenta replicar sobre a impossibilidade genética de tal fato, o que levantou a questão coloca que a genética tradicional estaria ultrapassada:

Mas explicar o quê? O presumível adultério da sua mulher com um oriental? Isso também não existe mais! Com a nova engenharia genética, fertilização artificial, sétuplos nascendo a três por quatro, clonagem, et cetera, quem mais pensa nisso? Se a sua mulher desse à luz sete ovelhas seria um fato jornalístico, mas não um fato moral. A cara do bebê não prova mais nada. $^{73}$

Diante da nova engenharia genética, isto é, das tecnologias que afetam a reprodução humana, questões morais perderiam a importância. A falta de semelhança física entre pai e filho não seria indício de adultério, porque o adultério deixaria de existir, não merecendo mais atenção diante das inovações. A geração de ovelhas por uma mulher não teria significado moral, embora guardasse interesse jornalístico. A mistura de espécies não teria peso moral. $O$ trecho da crônica acima relata a perplexidade diante das mudanças permitidas na reprodução humana e animal a partir da intervenção da ciência, mostrando um certo encantamento quanto ao progresso tecnológico. Em contraste com uma perspectiva em que a ciência, vista como exterior à sociedade, molda esta última, tentou-se considerar no presente texto a ciência enquanto criação da sociedade e integrante da cultura. Segundo Strathern, reivindicações de intervenção da sociedade na tecnologia como se fossem esferas separadas ocultam o fato de que a tecnologia é um processo social, enquanto a sociedade seria tecnologia em forma durável. ${ }^{74}$ Os procedimentos biomédicos dessas técnicas não apagam as relações sociais existentes. Pelo contrário, nas representações das novas tecnologias reprodutivas aqui discutidas, percebe-se que sua compreensão é mediada por concepções já existentes no tocante à condição de pessoa, às relações de gênero e de parentesco, evocando questões presentes em temas como $\circ$ aborto, $O$ incesto, a adoção, o adultério, a legitimidade dos filhos. 
NAARA LUNA

${ }^{75}$ FRANKLIN, 1999, p. 162-163.

${ }^{76}$ NOVAES e SALEM, 1995, p. $74 \mathrm{~s}$.
${ }^{77}$ FRANKLIN, 1999, p. 134-136, 159-165.
Em função desses valores já existentes, compreendese a polêmica que cerca o embrião. Este produto discursivo da embriologia, considerado um fato científico, emergiu como indivíduo e sujeito civil no final do século XX. ${ }^{75}$ Após ser colocado como centro do debate sobre a legalização do aborto que opunha os direitos da mãe aos direitos do feto, o surgimento do embrião concebido fora do corpo da mãe na fertilização in vitro reacende o debate sobre a pertinência de lhe atribuir condição de pessoa humana dotada de direitos individuais. Conforme demonstrado por Novaes e Salem, a complexificação da rede relacional que envolve um embrião concebido in vitro é ocultada por sua representação como unidade fisicamente independente, isto é, uma entidade 'flutuante solta' (free floating). ${ }^{76} \mathrm{O}$ embrião extracorporal poderia ser considerado um símbolo do ideal de indivíduo desprovido de relações.

Parentesco é reprodução no sentido de produzir gente inserida em uma rede social, dizendo respeito a gênero porque implica os papéis sexuais envolvidos na geração e na parentalidade. $\mathrm{O}$ aspecto técnico instrumental das novas tecnologias reprodutivas vem transformar o campo da reprodução humana, ampliando possibilidades, mas também confirmando tendências já existentes. No contexto da concepção assistida, evidencia-se o quanto os limites entre fato natural e fato social são indistintos. Franklin observa que, sendo a natureza assistida, o pressuposto ocidental da preeminência dos fatos biológicos é relativizado. A aquisição de identidade e a definição de parentalidade, temas considerados relacionais pela antropologia, são debatidas no discurso a-social e não-relacional dos fatos biológicos, paradoxalmente representando óvulos, esperma, zigotos e o concepto em termos sociais e relacionais, conforme se viu nos exemplos acima dos embrióes dotados de subjetividade. Este novo parentesco corporifica (embody) o progresso científico e tecnológico, sendo percebido como se acrescentasse a ordem da ciência às ordens dos fatos naturais e dos sociais. A natureza, além de culturalmente construída, estaria sendo fisicamente reconstruída, com o embrião corporificando natureza e progresso científico. 0 parentesco é então tecnologizado, geneticizado, com as fronteiras erguendo-se entre o ser humano e outras espécies. O parentesco é também individualizado, tornando-se a identidade genética essencial ao indivíduo. ${ }^{77}$ Os estudos de gênero e de parentesco devem levar em consideração a existência incorporada (embodied) das pessoas. A discussão sobre as novas tecnologias reprodutivas inclui o caráter incorporado da formação do ser humano, analisando processos sociais com respeito à intervenção humana na reprodução mediada por recursos da biomedicina. 


\section{Referências bibliográficas}

CALLIOLI, Eugênio Carlos. "Aspectos da fecundação artificial in vitro". Revista de Direito Civil, Imobiliário, Agrário e Empresarial. v. 12, n. 44, p. 71-95, abr./jun. 1988.

COLLIER, Jane Fishburne; YANAGISAKO, Sylvia Junko. "Introduction". In: Gender and Kinship: Essays Towards a Unified Analysis. Stanford: Stanford University Press, 1987. p. 1-13.

CONKLIN, Beth A.; MORGAN, Lynn M. "Babies Bodies and Production of Personhood in North America and in a Native Amazonian Society". Ethos, v. 24, n. 4, p. 657-694, 1996.

DOUGLAS, Mary. Pureza e perigo. São Paulo: Perspectiva, 1976.

DUMONT, Louis. Ensaios sobre o individualismo: uma perspectiva antropológica sobre a ideologia moderna. Lisboa: Dom Quixote, 1992. p. 13-30

. Homo hierarchicus: o sistema de castas e suas implicações. 2. ed. São Paulo: Edusp, 1997.

EDWARDS, Jeanette. "Explicit Connections: Ethnographic Enquiry in Northwest England. In: EDWARDS, J. et al. Technologies of Procreation: Kinship in the Age of Assisted Conception. 2. ed. New York: Routledge, 1999. p. 60-85.

EDWARDS, J. et al. Technologies of Procreation: Kinship in the Age of Assisted Conception. 2. ed. New York, Routledge: 1999a.

EDWARDS J. et al. "Introduction to the Second edition". In: EDWARDS, J. et al. Technologies of Procreation: Kinship in the Age of Assisted Conception. 2. ed. New York: Routledge, 1999b. p. 1-8. 2.

FRANKLIN, Sarah. "Making Representations: The Parliamentary Debate on the Human Fertilisation and Embriology Act". In: EDWARDS, J. et al. Technologies of Procreation: Kinship in the Age of Assisted Conception. 2. ed. New York: Routledge, 1999. p. 127-165.

HIRSCH, Eric. "Negotiated Limits: Interviews in South-East England". In: EDWARDS, J. et al. Technologies of Procreation: Kinship in the Age of Assisted Conception. 2. ed. New York, Routledge, 1999. p. 91-121.

LUNA, Naara Lúcia de Albuquerque. Bebê de proveta, barriga de aluguel, embriões de laboratório: as representações sociais das novas tecnologias reprodutivas. 2000. Dissertação (Mestrado em Antropologia Social) - Programa de Pós-Graduação em Antropologia Social, UFRJ, Rio de Janeiro.

NOVAES, Simone; SALEM, Tania. "Recontextualizando o embrião". Estudos Feministas, n. 3, v. 1, p. 65-88, 1995.

RIZZARDO, Arnaldo. "Fecundação artificial". Ajuris, v. 18, n. 52 , p. 62-78, jul. 1991. 
SALEM, Tania. "O princípio do anonimato na Inseminação Artificial com Doador (IAD)". Physis - Revista de Saúde Coletiva, v. 5, n. 1, p. 33-68, 1995.

SCHNEIDER, David. American Kinship: A Cultural Account. New Jersey: Prentice-Hall, 1968.

STRATHERN, Marilyn. "Disparities of Embodiment: Gender Models in the Context of the New Reproductive Technologies". Cambridge Anthropology, v. 15, n. 2, p. 25-43, 1991.

. Reproducing the Future: Essays on Anthropology, Kinship and the New Reproductive Technologies. Manchester: Manchester University Press, 1992.

"New Knowledge for Old? Reflections Following Fox's Reproduction and Succession". Social Anthropology, v. 2, n. 3, p. 263-279, 1994.

"Necessidade de pais, necessidade de mães". Estudos Feministas, Rio de Janeiro, v. 3, n. 2, p. 303-329, 1995a. "New families for Old?" In: Ulanowsky, Carole (Ed.). The Family in the Age of Biotechnology. Aldershot: Avebury, 1995b. p. 27-45.

"Enabling Identity? Biology, Choice and the New Reproductive Technologies". In: HALL, S. and GAY, P. (Eds.). Questions of Cultural Identity. London: Sage, 1996. p. 3752.

"Surrogates and Substitutes: New Practices for Old?". In: GOOD, James and VELODY, Irving (Eds.). The Politics of Postmodernity. Cambridge: Cambridge University Press, 1998. p. 182-209.

. "A Question of Context". In: EDWARDS, J. et al. Technologies of Procreation: Kinship in the Age of Assisted Conception. 2. ' ed. New York: Routledge, 1999a. p. 9-28. "Regulation, Substitution and Possibility". In: EDWARDS, J. et al. Technologies of Procreation: Kinship in the Age of Assisted Conception. 2. ed. New York: Routledge, 1999b. p. 171-216.

[Recebido para publicação em novembro de 2000]

\section{Personhood and Kinship in the New Reproductive Technologies}

Abstract: This article deals with the universe of representations of new reproductive technologies and analyzes the consequences of those procedures for Western notions of personhood and kinship. These techniques affect Western ways of thinking about reproduction and human control over nature. Reports of embryos created outside the maternal body by in vitro fertilization are examined to consider notions of personhood. The understanding of new reproductive technologies informs and is informed by representations of kinship. The analysis of the relation between technologies of procreation, kinship and personhood takes into account Western beliefs on nature as a foundation for reality. The research draws on articles published in the Brazilian press between 1994 and 2000.

Keywords: new reproductive technologies, personhood, kinship, embryo, nature. 